\title{
Oncogenic Mutation Frequencies in Lung Cancer Patients
}

\section{Akciğer Kanseri Hastalarında Onkojenik Mutasyon Sıklıkları}

\author{
๑ Ömer Ayten ${ }^{1}, \odot$ Tayfun Çalışkan ${ }^{1}, \oplus$ Kadir Canoğlu ${ }^{1}, \oplus$ Neslihan Kaya Terzi², \\ ๑ Levent Emirzeoğlu ${ }^{3}$, Oğuzhan Okutan ${ }^{1}$ \\ ${ }^{1}$ University of Health Sciences Turkey, Istanbul Sultan 2. Abdülhamid Han Tranining and Research Hospital, Clinic of Pulmonology, İstanbul, Turkey \\ ${ }^{2}$ University of Health Sciences Turkey, İstanbul Sultan 2. Abdülhamid Han Tranining and Research Hospital, Clinic of Pathology, İstanbul, Turkey \\ ${ }^{3}$ University of Health Sciences Turkey, Istanbul Sultan 2. Abdülhamid Han Tranining and Research Hospital, Clinic of Medical Oncoloy, Istanbul, Turkey
}

Background: The data on mutation frequencies in patients with lung cancer are limited in Turkey. We aimed to determine the frequencies of $E G F R, A L K, R O S 1$, and BRAF gene mutations in patients with lung cancer in this study.

Materials and Methods: Data of 329 patients with lung cancer, who underwent molecular examination at the İstanbul Sultan 2. Abdülhamid Han Training and Research Hospital, Clinic of Medical Pathology Laboratory, were analyzed retrospectively.

Results: A total of 329 patients with lung cancer, of whom 257 were male and 71 were female, were included in the study. The average age of women was $65.7 \pm 11.2$ years and the average age of men was $64.6 \pm 10.3$ years. Thirty nine patients (11.8\%) were non-smokers. The prevalence of smoking was $97.2 \%(n=251)$ in male patients and $54.9 \%(n=39)$ in female patients. Two hundred sixty one (79.3\%) of the patients had adenocarcinoma, 50 (15.2\%) squamous cell lung cancer, 13 (3.9\%) non-small cell lung cancer, $4(1.3 \%)$ small cell lung cancer, 1 patient $(0.3 \%)$ was diagnosed with large cell lung cancer. Gene mutation was detected in 52 patients (15.8\%). EGFR mutation was detected in 32 patients (9.7\%),ALK in 17 patients (5.5\%), ROS1 in 2 patients (0.6\%), and BRAF mutation in 1 patient (0.3\%). The frequency of mutation was $30.7 \%(n=12)$ in non-smoking patients, and $18.2 \%(n=53)$ in smokers. The most common genetic alteration was deletions in the EGFR gene in exon 19.

Conclusion: In our study, we found the frequencies of EGFR and ALK mutations similar to the studies conducted around the world but BRAF and ROS1 mutations frequencies were lower compared to studies conducted around the world. In addition, we found that all mutation frequencies were lower than in studies conducted in our country. We thought this was related to the low number of cases in the studies and more selective patient selection.

Keywords: Lung cancer, oncogenic mutations, EGFR, ALK, ROS1, BRAF

Amaç: Ülkemizde akciğer kanseri hastalarında mutasyon sıklıkları ile ilgili veriler sınırlıdır. Çalışmamızda akciğer kanserli hastalarda EGFR, ALK, ROS1, BRAF, gen mutasyonlarının sıklıklarının belirlenmesi amaçlanmıştır

Gereç ve Yöntemler: İstanbul Sultan 2. Abdülhamid Han Eğitim Araştırma Hastanesi, Tıbbi Patoloji Kliniği Laboratuvarı'nda moleküler incelemeye alınan, akciğer kanseri tanılı toplam 329 hastanın verileri retrospektif olarak incelendi.

Bulgular: Akciğer kanseri tanılı 258'i erkek ve 71'i kadın toplam 329 hasta çalışmaya dahil edildi. Kadın hastaların ortalama

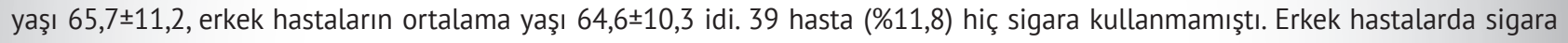
kullanma sıklı̆ı \%97,2 (n=251), kadın hastalarda sigara kullanma sıklığı \%54,9 (n=39) idi. Hastaların 261’i (\%79,3) adenokanser, 50'si (\%15,2) squamoz hücreli akciğer kanseri, 13'ü $(\% 3,9)$ küçük hücreli dışı akciğer kanseri, 4’ü $(\% 1,3)$ küçük hücreli akciğer kanseri, 1 hasta (\%0,3) da büyük hücreli akciğer kanseri tanılı idi. Elli iki hastada $(\% 15,8)$ gen mutasyonu saptandı. Otuz iki hastada $(\% 9,7)$ EGFR, 17 hastada $(\% 5,5)$ ALK, 2 hastada $(\% 0,6)$ ROS1, 1 hastada $(\% 0,3)$ BRAF mutasyonu saptandı. Sigara içmeyen hastalarda mutasyon sıklığı \%30,7 ( $n=12)$, sigara içenlerde mutasyon sıklığı \%18,2 ( $n=53)$ bulundu. Sigara içmeyen hastalarda 10 hastada EGFR $(\% 25,6), 2$ hastada $(\% 5,1)$ ise ALK mutasyonu pozitif saptandı. En sık saptanan genetik değişiklik EGFR geninde ekzon 19'da saptanan delesyonlardı.

Address for Correspondence: Ömer Ayten, University of Health Sciences Turkey, İstanbul Sultan 2. Abdülhamid Han Tranining and Research Hospital, Clinic of Pulmonology, ìstanbul, Turkey

Phone: +90 5053695475 E-mail: omerayten2002@yahoo.com ORCID ID: orcid.org/0000-0002-2275-4378

Received: 03.09.2020 Accepted: 17.09.2020 
Sonuç: Çalışmamızda EGFR ve ALK mutasyon sıklıklarını dünyada yapılan çalışmalarla benzer bulduk. Ancak BRAF ve ROS1 mutasyon sıklıkları dünyada yapılan çalışmalara göre daha düşüktü. Ayrıca tüm mutasyon sıklıklarının ülkemizde yapılan çalışmalara göre daha düşük olduğunu saptadık. Bu durumun yapılan çalışmalardaki düşük olgu sayısı ve daha selektif hasta seçimi ile ilgili olabileceğini düşündük.

Anahtar Kelimeler: Akciğer kanseri, onkojenik mutasyonlar, EGFR, ALK, ROS1, BRAF

\section{Introduction}

Lung cancer is still the leading cause of cancer deaths worldwide (1). There are 1.8 million new cases with lung cancer and 1.6 million people die due to lung cancer per year (2). Non-small cell lung cancers (NSCLC) are $80 \%$ of lung cancers (3). Since the majority of cases are diagnosed at an advanced stage, the mortality is high. The standard chemotherapy regimens applied so far have not had a dramatic effect on the prognosis (5-year survival 15\%) (4). In recent years, a better understanding of the pathogenic genomic changes of NSCLC and determination of molecular tests and biomarkers used to identify patients with these genomic changes have enabled the use of molecular target therapies and immunotherapy in advanced stage patients with NSCLC, especially for adenocarcinoma. Pharmacological treatments guided by epidermal growth factor receptor (EGFR), anaplastic lymphoma kinase (ALK), proto-oncogene receptor tyrosine kinase 1 (ROS1) and V-Raf murine sarcoma viral oncogene homolog $B$ (BRAF) driver mutations have opened a new era in the treatment of advanced lung cancer. Although many mutations have been identified in lung cancer, the mutation status is still unknown in more than $50 \%$ of patients with lung cancer and therapeutic targets can be determined only in $20 \%$ of the patients (5).

The detection of EGFR, ALK, ROS1 and BRAF in patients with advanced stage or metastatic adenocarcinoma and NSCLC, whose histologically clear distinction cannot be made, and in patients with squamous cell carcinoma and no history of smoking is currently recommended (6). Therefore, adequate biopsies are needed to perform molecular examination along with histopathological diagnosis.

The data on mutation frequencies in patients with lung cancer are limited in Turkey. We aimed to determine the frequencies of $E G F R, A L K, R O S 1, B R A F$ gene mutations in patients with lung cancer in this study.

\section{Material and Methods}

A total of 329 patients with lung cancer were included in the study. The samples were performed molecular examination at the İstanbul Sultan 2. Abdülhamid Han Training and Research Hospital, Clinic of Medical Pathology Laboratory between 2017 and 2019. Ethics committee approval of the study was obtained (number: 57 and date: 18/03/2020). Preoperative approvals were obtained from all patients. Age, gender, smoking history and histopathological diagnoses of the patients were recorded. For EGFR gene exon 18, 19, 20, 21 and BRAF gene exon 15 mutation analyses, the area containing the most tumor cells in the Hematoxylin \& Eosin (H\&E) stained section was determined. Tumor areas determined from 10 unstained histological tissue sections of $10 \mu \mathrm{m}$ thicknesses were manually macro dissected with a scalpel. After standard deparaffinization and hydration, DNA was isolated with the QIAamp FFPE Tissue kit. DNA concentration of the samples was measured spectrophotometrically (nanodrop). The $18^{\text {th }}$, $19^{\text {th }}, 20^{\text {th }}, 21^{\text {st }}$ exons of the EGFR gene and the $15^{\text {th }}$ exons of the BRAF gene were amplified by polymerase chain reaction (PCR) in the thermal cycler using the HotStar Taq DNA Polymerase kit and appropriate primers. The sample was run in pairs with positive, negative and noDNA template controls. Density and contamination control of PCR products was done by gel electrophoresis process. PCR products were purified with the QIAquick PCR Purification kit. Two-way (forward and reverse) DNA sequence analysis was performed on the purified amplicons using the Big Dye Terminator v3.1 Cycle Sequencing kit with the Sanger sequence technique. After ethanol precipitation, PCR products were run on the ABI-3730 (48 capillary) automatic sequencing device. The resulting electropherograms were visually evaluated using SeqScape Software 3.0 by comparing them with the reference sequences NM_005228.3 (EGFR gene) and NM_004333.4 (BRAF gene), together with their positive and negative controls.

In order to investigate the ALK and ROS1 genes by FISH technique, the area containing the most tumor cells in the $\mathrm{H} \& \mathrm{E}$ stained section was determined. After the macrodissection of the $2 \mu \mathrm{m}$ thick section taken from the formal-fixed paraffin embedded block, it was prepared by standard prehybridization steps. "ZytoLight SPEC ROS1 Dual Color Break Apart Probe, Z-2144-200,Zytovision" (proximal part of the breakpoint region of the ROS1 gene (6q22.1): green spectrum, distal part: orange spectrum) and reconstruction in $A L K$ gene for evaluation of rearrangement in the ROS1 gene; using "ZytoLight SPEC ALK Dual Color Break Apart Probe, Z-2124-200,Zytovision" (proximal part of the breakpoint region of the ALK gene (2p23.1-p23.2): 
green spectrum, distal part: orange spectrum) for the evaluation of regulation, standard FISH process was applied. One hundred tumor cells were evaluated using Leica DM 2.500 fluorescence microscope and Argenit Akas imaging system.

\section{Statistical Analysis}

No statistical analysis was needed.

\section{Results}

A total of 329 patients with lung cancer, of whom 257 were male and 71 were female, were included in the study. The average age of the patients was $64.9 \pm 10$ years. The mean age of women was $65.7 \pm 11.2$ years and the mean age of men was $64.6 \pm 10.3$ years. 39 patients $(11.8 \%)$ were non-smokers. The prevalences of smoking of male and female patients were $97.2 \%(n=251)$ and $54.9 \%(n=39)$, respectively. Two hundred sixty one $(79.3 \%)$ of the patients were diagnosed as adenocarcinoma, $50(15.2 \%)$ of the patients were diagnosed as squamous cell lung cancer (SCC), 13 (3.9\%) of the patients were diagnosed as NSCLC, 4 (1.3\%) of the patients were diagnosed as small cell lung cancer (SCLC) and 1 patient (0.3\%) was diagnosed as large cell lung cancer (Table 1 ). Gene mutation was detected in 52 patients (15.8\%). EGFR mutation was detected in 32 patients ( $9.7 \%)$, ALK was positive in 17 patients (5.5\%), ROS1 was positive in 2 patients ( $0.6 \%$ ), and BRAF mutation was positive in 1 patient $(0.3 \%)$. Thirty of the patients, whose biopsies were positive for EGFR, were diagnosed as adenocarcinoma, 1 patient was diagnosed as SCLC (transformed from adenocarcinoma) and 1 patient was diagnosed as SCC. One of the patients with positive ALK mutation was diagnosed as SCC and 16 were diagnosed as adenocarcinoma. All of the patients with positive ROS1 and BRAF mutations were diagnosed as adenocarcinoma (Table 2). The frequency of mutation was $30.7 \%(n=12)$ in non-smoking patients, and $18.2 \%(n=53)$ in smokers. EGFR (25.6\%) was positive in 10 and ALK mutation was positive in 2 of the nonsmoking patients (5.1\%). The most common genetic alteration was deletions in the EGFR gene in exon 19 (Table 3).

\section{Discussion}

Genomic changes and mutations in lung cancer vary in different populations. While the incidence of EGFR, ALK, ROS1 and BRAF mutations in patients with adenocarcinoma is approximately $30 \%$ in the Uninted States of America, this rate is $60 \%$ in Japan $(7,8)$. Çalıskan et al. (9) detected at least one gene mutation in 37 $(46.2 \%)$ of 80 patients with lung cancer in a Turkish population. Bilgin et al. (10) detected at least one gene mutation in 60 (22.9\%) of 260 NSCLC patients and EGFR was positive in 38 (14.6\%), ALK was positive in 20 (7.69\%), and ROS1 was positive in $2(0.76 \%)$ of them. In our study, we found at least one gene mutation in $15.8 \%$ ( $n=52)$ of the patients. High mutation detection rate in the studies of Çalıskan et al. (9) and Bilgin et al. (10) may be related to the low number of patients and the more specific patient selection.

Although the true incidence of EGFR mutation in lung cancers is unknown, the incidence varies between 0 and 13\% $(11,12)$. EGFR mutation is more common in female non-smoking patients with adenocarcinoma. In our study, the frequency of EGFR mutation was found to be $9.7 \%$, and $93.7 \%(n=30)$ of the patients with positive EGFR mutation had adenocarcinoma. One patient was diagnosed as SCC, and the diagnosis of one patient was transformed from adenocarcinoma to small cell lung cancer. Similar to the literature, the frequency of EGFR mutations was higher in patients who never smoked ( $n=10,25.6 \%)$.

The frequency of ALK rearrangement in NSCLC is between $4 \%$ and 5\% (13). In our country, Bilgin et al. (10) reported that 20 (7.69\%) of 260 NSCLC patients were positive for ALK mutation, Seymen and Gümüşlü (14) detected ALK rearrangement in $8(16 \%)$ of 1450 NSCLC patients. Aytekin (15) detected ALK rearrangement in 2 (5.1\%) of 130 lung cancer patients, 36 of whom had adenocarcinoma. In our study, the frequency of ALK rearrangement was $5.5 \%$, similar to the literature. The frequency of ALK rearrangement was higher in female patients $(n=6,8.4 \%)$.

The frequency of ROS1 rearrangement in NSCLCs varies between $1 \%$ and $2 \%$ (16). ROS1 rearrangement is observed more frequently in young and non-smoking patients. In a limited number of studies on the frequency of ROS1 rearrangement in Turkey, the frequency varies between $0 \%$ and $0.76 \%(10,15)$. In our study, in contrast to the literature, ROS1 rearrangement was detected in 2 male patients ( $0.6 \%$ ) over 65 years of age with a history of smoking and they were diagnosed as adenocarcinoma. BRAF mutations are observed in 1-3\% of patients with NSCLC. It is observed more frequently in patients with a smoking history. Dogan et al. (17) detected BRAF mutation in 1 (2.38\%) of 42 patients with advanced NSCLC in their study. Çalıskan et al. (9) detected BRAF mutation in 1 patient (1.25\%) of 80 NSCLC patients. In our study, BRAF mutation was found in 1 male patient $(0.3 \%)$ with an active smoking and diagnosis of adenocarcinoma.

\section{Conclusion}

In our study, we found the frequencies of EGFR and ALK mutations similar to the studies conducted around the world but the frequencies of BRAF and ROS1 mutations were lower compared to studies conducted around the world. In addition, we found that all mutation frequencies were lower than in studies conducted in our country. We thought this was related to the low number of cases in the studies and more selective patient selection. Our study is one of the largest series of studies on 


\begin{tabular}{|c|c|c|c|c|}
\hline Variables & & $\begin{array}{l}\text { Female }(n=71) \\
(21.6 \%)\end{array}$ & $\begin{array}{l}\text { Male }(n=258) \\
(78.4 \%)\end{array}$ & $\begin{array}{l}\text { Total }(n=329) \\
(100 \%)\end{array}$ \\
\hline Age & (Min-max) & $34-89$ & $32-89$ & $32-89$ \\
\hline Smoking & Yes & 39 (54.9) & $251(97.2)$ & $290(88.2)$ \\
\hline \multicolumn{5}{|l|}{ Histology } \\
\hline Adenocarcinoma & & 64 (90.2\%) & 197 (76.3\%) & $261(79.3 \%)$ \\
\hline Squamous cell carcinoma & & $2(2.8 \%)$ & $48(18.6 \%)$ & 50 (15.2\%) \\
\hline Non-small cell carcinoma & & $4(5.6 \%)$ & 9 (3.49\%) & $13(3.9 \%)$ \\
\hline Small cell carcinoma & & $1(1.4 \%)$ & $3(1.2 \%)$ & $4(1.3 \%)$ \\
\hline
\end{tabular}

\section{Table 2. Mutation frequencies according to lung cancer histologic types}

\begin{tabular}{|c|c|c|c|c|c|c|}
\hline \multirow[t]{2}{*}{ Gene } & \multicolumn{5}{|c|}{ Histology of lung cancer } & \multirow[b]{2}{*}{$\begin{array}{l}\text { Total } \\
(n=329)\end{array}$} \\
\hline & $\begin{array}{l}\text { Adenocarcinoma } \\
(n=261)\end{array}$ & $\begin{array}{l}\text { Squamous cell } \\
\text { carcinoma } \\
(n=50)\end{array}$ & $\begin{array}{l}\text { Non-small cell } \\
\text { carcinoma } \\
(n=13)\end{array}$ & $\begin{array}{l}\text { Small cell } \\
\text { carcinoma } \\
(n=4)\end{array}$ & $\begin{array}{l}\text { Large cell } \\
\text { carcinoma } \\
(n=1)\end{array}$ & \\
\hline EGFR & 30 (11.5\%) & $1(2 \%)$ & - & $1^{*}(25 \%)$ & - & 32 (9.7\%) \\
\hline$A L K$ & $16(6.1 \%)$ & $1(2 \%)$ & - & - & - & $17(5.5 \%)$ \\
\hline ROS1 & $2(0.76 \%)$ & - & - & - & - & $2(0.6 \%)$ \\
\hline
\end{tabular}

*: Transformation from adenocarcinoma, EGFR: Epidermal growth factor receptor, ALK: Anaplastic lymphoma kinase, ROS1: Poto-oncogene receptor tyrosine kinase 1, BRAF: V-Raf murine sarcoma viral oncogene homolog $B$

\section{Table 3. Molecular alterations determined in the study}

\begin{tabular}{|c|c|c|}
\hline Gene & Molecular subtypes & Molecular alterations \\
\hline \multirow{4}{*}{ EGFR } & Exon 18 & c. $2155 \mathrm{G}>\mathrm{T}$ \\
\hline & Exon 19 & $\begin{array}{l}\text { c.2237_2255>T, c.2239_2248TTAAGAGAAG>C, c.2235_2249del15, c.2239_2256del18, } \\
\text { c.2240_2257del18, c.2239_2253del15, c.2240_2254del15, c.2237_2251del15, } \\
\text { c.2237_2252delinsT, c.2239_2248delinsC, p.L747_A750de }\end{array}$ \\
\hline & Exon 20 & $\begin{array}{l}\text { c.2311_2312insGCGTGGACA, c.2313_2314insACG, c.2369C>T, c.2296_2297insTGGCCAGCG, } \\
\text { c.2464G>A }\end{array}$ \\
\hline & Exon 21 & c. $2573 \mathrm{~T}>\mathrm{G}, \mathrm{c} .2582 \mathrm{~T}>\mathrm{A}$ \\
\hline$A L K$ & EML4-ALK & rearrangement in $2 q 23$ region \\
\hline ROS1 & ROS1 & rearrangement in 6q22 region \\
\hline$B R A F$ & Exon 15 & c.1799T $>A$ \\
\hline
\end{tabular}

mutation frequencies in lung cancers in Turkey. For this reason, it is of great importance to reveal mutation frequencies with more molecular studies in our country and to popularize the treatments for this.

\section{Ethics}

Ethics Committee Approval: Ethics committee approval of the study was obtained (number: 57 and date: 18/03/2020). 
Informed Consent: Preoperative approvals were obtained from all patients.

Peer-review: Internally peer-reviewed.

\section{Authorship Contributions}

Concept: Ö.A., T.Ç., K.C., O.O., Design: Ö.A., T.Ç., L.E., O.O., Data Collection or Processing: Ö.A., T.Ç., K.C., N.K.T., L.E., Analysis or Interpretation: Ö.A., T.Ç., K.C., N.K.T., L.E., Literature Search: Ö.A., T.Ç., K.C., O.O., Writing: Ö.A., T.Ç.

Conflict of Interest: No conflict of interest was declared by the authors.

Financial Disclosure: The authors declared that this study received no financial support.

\section{References}

1. Siegel RL, Miller KD, Jemal A. Cancer statistics, 2016. CA Cancer J Clin. 2016;66:7-30. [Crossref]

2. Ferlay J, Soerjomataram I, Dikshit R, Eser S, Mathers C, Rebelo M, et al. Cancer incidence and mortality worldwide: sources, methods and major patterns in GLOBOCAN 2012. Int J Cancer. 2015;136:E359-E386. [Crossref]

3. Soda M, Choi YL, Enomoto M, Takada S, Yamashita Y, Ishikawa Y, et al. Identification of the transforming EML4-ALK fusion gene in non-smallcell lung cancer. Nature. 2007;448:561-566. [Crossref]

4. Parkin DM, Bray F, Ferlay J, Pisani P. Global cancer statistics, 2002. CA Cancer J. Clin. 2005;55:74-108. [Crossref]

5. Herbst RS, Heymach JV, Lippman SM. Lung cancer. N Engl J Med. 2008; 359:1367-1380. [Crossref]

6. Ettinger DS, Wood DE, Aggarwal C, Aisner DL, Akerley W, Bauman JR, et al. NCCN Guidelines Insights: Non-Small Cell Lung Cancer, Version 1.2020. J Natl Compr Canc Netw. 2019;17:1464-1472. [Crossref]

7. Lindeman NI, Cagle PT, Aisner DL, Arcila ME, Beasley MB, Bernicker EH, et al. Updated molecular testing guideline for the selection of lung cancer patients for treatment with targeted tyrosine kinase inhibitors: guideline from the College of American Pathologists, the International Association for the Study of Lung Cancer, and the Association for Molecular Pathology. J Thorac Oncol. 2018;13:323-358. [Crossref]

8. Kohno T, Nakaoku T, Tsuta K, Tsuchihara K, Matsumoto S, Yoh K, et al. Beyond ALK-RET, ROS1 and other oncogene fusions in lung cancer. Transl Lung Cancer Res. 2015;4:156-164. [Crossref]

9. Çalıskan M, Bozkurt G, Meydan N, Meteoğlu İ, Günel NS. Küçük Hücreli Dışı Akciğer Kanseri Hastalarında Onkogen Mutasyonlarının Araştırılması. Med J SDU. 2018:25:322-328. [Crossref]

10. Bilgin B, Yücel Ş, Yılmaz Ü. The Efficacy of Pemetrexed-Based Therapy in Advanced Lung Adenocarcinoma with Targetable Driver Mutation: A RealLife Experience.J Oncol Sci. 2020;6:43-48. [Crossref]

11. Mitsudomi T, Kosaka T, Endoh H, Horio Y, Hida T, Mori S, et al. Mutations of the epidermal growth factor receptor gene predict prolonged survival after gefitinib treatment in patients with non-small-cell lung cancer with postoperative recurrence.J Clin Oncol. 2005;23:2513-2520. [Crossref]

12. Chou TY, Chiu CH, Li LH, Hsiao CY, Tzen CY, Chang KT, et al. Mutation in the tyrosine kinase domain of epidermal growth factor receptor is a predictive and prognostic factor for gefitinib treatment in patients with non-small cell lung cancer. Clin Cancer Res. 2005;11:3750-3757. [Crossref]

13. Chia PL, Mitchell P, Dobrovic A, John T. Prevalence and natural history of ALK positive non-small-cell lung cancer and the clinical impact of targeted therapy with ALK inhibitors. Clin Epidemiol. 2014;6:423-432. [Crossref]

14. Seymen PN, Gümüşlü E. Küçük Hücreli Dışı Akciğer Kanserinde ALK Geninin Yeniden Düzenlenmesinin FISH Yöntemi ile Belirlenmesi. JAREM. 2019;9:66-70. [Crossref]

15. Aytekin A. Investigation of EGFR mutation and ALK gene rearrangement rates in lung adenocarcinoma patients in Mardin. Medical Science and Discovery. 2019;6:292-294. [Crossref]

16. Shea M, Costa DB, Rangachari D. Management of advanced non-small cell lung cancers with known mutations or rearrangements: latest evidence and treatment approaches. Ther Adv Respir Dis. 2016;10:113-129. [Crossref]

17. Dogan M, Demirkazık A, Tukun A, Sak SD, Ceyhan K, Yalcın B, et al. The Relationship Between Common EGFR, BRAF, KRAS Mutations and Prognosis in Advanced Stage Non-Small Cell Lung Cancer with Response to the Treatment in Turkey. Int J Hematol Oncol. 2014;24:1-10. [Crossref] 